\title{
The influence of oxytetracycline and vita-stress supplement on the productive performance of broiler chickens in the semi-arid zone of Nigeria
}

\author{
H. Duwa ${ }^{1}$, I. D. Kwari ${ }^{1}$, B. Saleh ${ }^{1}$ and $*$ I. B. Amaza ${ }^{2}$ \\ ${ }^{I}$ Department of Animal Science, University of Maiduguri, P.M.B. 1069, Borno State, Nigeria \\ ${ }^{2}$ Nigerian Institute of Animal Science, Northeast Zonal Office, Maiduguri, Borno State Nigeria
}

\begin{abstract}
The effect of an antibiotic, oxytetracycline Hcl and a vitamin supplement on the performance and cost of production of broiler chickens were investigated in the semi-arid zone of Nigeria using eighty four Anak 2000 breed of broilers in a study which lasted for nine weeks. Oxytetracycline antibiotic and vita-stress were given to the broilers as prescribed by the manufacturers to supplement the commercial broiler starter and finisher diets as follows: Treatment 1 (Basal diet only $-T_{1}$ ) (control), Treatment 2 (Basal diet + oxymed injectable $-T_{2}$ ), Treatment 3 (Basal diet + vita-stress in water $-T_{3}$ ) and Treatment 4 (Basal diet + oxymed injectable + vita-stress in water $-T_{4}$ ). Results of the study showed that supplementation of broiler chicken feeds with oxytetracycline $\mathrm{Hcl}$ antibiotic and vita-stress $\left(T_{4}\right)$ significantly $(P<0.05)$ improved the chicken body weight gain of the birds at different periods of the study, although the overall mean body weight gain of all the experimental groups did not differ $(P>0.05)$ from one another. Mortality records however, showed broiler finisher diets with oxytetracycline or vita-stress, lowered mortality rates of birds in $T_{2}, T_{3}$ and $T_{4}$ treatment groups. Evaluation of the cost of production shows that supplement of feeds with oxytetracycline and vitastressed increased the cost of production without significant gain in revenue at the end of the study. The results of the study therefore shows that supplementation of broiler diets with oxytetracycline or vita-stress which is practiced in the North-Eastern States of Nigeria during the hot weather do not improve live weight gain in broilers but decreased the mortality rates of the birds.
\end{abstract}

Key words: Performance, oxytetracycline, vita-stress

\section{Introduction}

The uses of antibiotics and vitamins (vita-stress) in animal production as feed additives for growth performance and disease control have received a great deal of numerous reports in the scientific literature.

Antibiotics are chemical substances produced by microorganisms (Brander, 1986). They are restricted to compounds of microbial origin specially produced to combat other injurious micro-organisms, notably bacteria. Antibiotics are not equally effective against all microorganisms and viruses. The range of disease for which an antibiotic is effective is termed its anti-microbial spectrum. Brander (1986) classified antibiotics into two main classes. Antibiotics may either be bacteriostatic or bacteriocidal depending on their mechanism of action and the dosage given. They act in diverse ways upon more than one of the countless biochemical activities of organisms. They decrease mortality rate, improve feed efficiency, control stress and enhance utilization of calcium and phosphorus and other nutrients.

Antibiotics spare the requirement for protein, certain vitamins and minerals. In addition, they make the intestine more acidic, improve absorption and stimulate bone growth. Continous use of antibiotics is necessary to prevent re-infestation of organisms with harmful micro flora and lastly, they invade organisms which compete with the host for available nutrients.

Oxymed (oxytetracycline Hc1), which is a broad spectrum antibiotic is well absorbed in the gastrointestinal tract and from intramuscular injections. After absorption, it is well distributed in the body tissues and fluids except cerebrospinal fluid. The anti-microbial effect of oxymed reduces stress in poultry thus egg production and egg quality are improved in laying hens (Briggs, 1950).

Vitamins are first recognized as dietary accessory factors needed in trace amounts to maintain normal health, well being and reproductive capacity in animals and man. Lack of one or more of these factors may lead to certain distinctive "deficiency syndrome". Such minute amounts are required that it seemed reasonable to term vitamins as playing catalytic role and in many instances, this has proved true.

Vita-stress on the other hand is useful for its nutritive value. It is an effective vitamin supplement that can prevent and cure vitamin deficiency diseases, improve growth rate and efficiency of feed utilization. The objective of this study was to determine the effect of oxymed (oxytetracycline Hc1) and vita-stress ion productive performance of broiler chickens in a semi-arid environment. 


\section{Materials and Methods}

\subsection{Experimental Stock and Management}

This experiment was conducted at the University of Maiduguri Poultry Teaching and Research Farm, during the months of March to May when the mean day temperature was $40^{\circ} \mathrm{C}$. Eighty four broiler chicks were used for the study which lasted for nine weeks. The chicks were individually weighed, randomly selected and allocated to each of the four treatments. Each treatment consisted of 21 birds and was replicated 3 times with 7 birds per replicate.

The treatments comprised:

$\mathrm{T}_{1}$-(Control)-Basal diet only

$\mathrm{T}_{2}$-Basal diet + oxymed injectable

$\mathrm{T}_{3}$-Basal diet + Vita-stress in water

$\mathrm{T}_{4}$-Basal diet + oxymed injectable + vita-stress in water

The birds were fed commercial broiler starter from day-old to 4 weeks of age and broiler finisher from 5 weeks to 9 weeks as basal diets. The birds were vaccinated against Gumboro disease at two and five weeks of age, New Castle disease at three weeks of age and fowl pox at six weeks of age. Water and feed were provided $\underline{a d}$ libitum throughout the experimental period.

\subsection{Composition of the test materials}

The oxymed (oxytetracycline Hc1) consisted of (i) oxytetracycline Hcl B.P. 50.0g and (ii) Magnesium complex contained in $100 \mathrm{ml}$ per bottle. On the other hand, vita-stress (vitamin) contains vitamin 'A', vitamin 'D3', vitamin ' $\mathrm{E}$ ', thiamin mononitrate, riboflavin, niacin amide, vitamin 'B6' pyridoxine $\mathrm{HCl}$, vitamin 'B12', vitamin ' $\mathrm{K}$ ' activity, folic acid and calcium pantothenate. The administration of the oxymed depended on the body weight of the birds $(1 \mathrm{ml} / 10 \mathrm{~kg}$ body weight) while a sachet of vita-stress which was $50 \mathrm{~kg}$ was diluted in $100 \mathrm{ml}$ of water and is administered via drinking water.

\subsection{Parameters Measured}

Individual body weight of the birds was obtained to the nearest $0.1 \mathrm{~g}$ on the first day of the study and weekly thereafter. Mean body weight gain and mean feed consumption were calculated weekly and feed efficiency was also calculated weekly as the ratio of the feed intake to the body weight gain.

All the data were subjected to analysis of variance using the randomized complete block design and where significant differences among treatment means were observed, the means were separated using least significant difference (LSD) (Steel and Terrie, 1980).

\section{Results and Discussion}

Weekly live weight gain $(\mathrm{g})$. There were no significant $(\mathrm{P}>0.05)$ differences among the overall means for all the treatments (Table 1) although the birds in treatment 4 gained slightly more weight than the rest of the groups. A comparison of live weight gain on weekly basis revealed that there were significantly $(\mathrm{P}<0.05)$ differences at certain periods of the study. Birds in treatment 4 performed much better than their counterparts in treatment 1, 2 and 3 at weeks 1, 2, 3, 6 and 9 of age (Table 1). However, the birds in treatment 3 gained more weight $(\mathrm{P}<0.05)$ at weeks 5 and 7 than those in treatments 1 and 2 , while at week 8 , the birds in treatment 2 were significantly $(\mathrm{P}<0.05)$ heavier than those in treatments 1,3 and 4 . This may be as a result of the complementary effect of the two supplements (antibiotics and vita-stress). In this study, the significant $(\mathrm{P}<0.05)$ differences observed at various ages of the experimental birds could have been in part due to variation among the dietary treatments coupled with the bird's reaction to the high environmental temperatures which prevailed throughout the experimental period. Kelly and Potter (1971) stated that such adaptive changes varied with individual birds.

\subsection{Weekly feed consumption}

The data for weekly feed consumption are presented in Table 2 . The overall weekly means for feed consumption for $T_{1}, T_{2}, T_{3}$ and $T_{4}$ are $771.41,780.17,763.73$ and 769.13 respectively. There are no significant $(\mathrm{P}>0.05)$ differences among the treatments although the birds in treatment 2 consumed the highest feed than the other treatment groups.

The weekly feed consumption increased progressively with the age of the birds throughout the experimental period; with birds in treatment 2 consuming significantly $(\mathrm{P}<0.05)$ more feed than others at week 5, 6, 8 and 9. Treatment 1 (Control) birds also consumed at week 1, 2, and 4. Similarly, birds in treatment 4 consumed significantly $(\mathrm{P}<0.05)$ more feed at weeks 3 and 7 than the birds in treatments 1 and 2 and $\mathrm{T} 3$ treated birds consumed more $(\mathrm{P}<0.05)$ feeds at weeks 3 and 7 than the rest of the groups. This observation is similar to the report of Fernandez et al. (1973) which showed that chicken fed bacitracin, an antibiotic improved feed consumption and efficiency when Aureomycin was added to the diets of birds. A similar observation was 
reported by Menge (1973) when addition of oxytetracycline to feeds failed to improve feed consumption and feed conversion efficiency of the experimental birds. However, Contor and Johnson (1983) reported that Turkey Poults give greater response to antibiotic supplementation than chicks.

\subsection{Feed efficiency}

The feed efficiency data is represented in Table 3. The overall means for treatments 1 (Control) 2.28, $\mathrm{T}_{2} 2.18, \mathrm{~T}_{3} 2.1$ and $\mathrm{T}_{4} 2.17$ were not significantly $(\mathrm{P}>0.05)$ different from one another.

\subsection{Mortality}

Mortality data are shown in Table 4 . The highest mortality rate of $33.3 \%$ was recorded in $\mathrm{T}_{1}$ (control), followed by $16.67 \%$ in treatments 2,3 and 4 . The deaths were recorded during weeks 8 and 9 but the highest rate was in week 9 . These deaths coincided with the time of high environmental temperatures and the postmortem results showed that the birds died of heat prostaton.

The result obtained in this study is in line with the report of McDougald and Mcquisition (1980) who stated that losses due to heat stress particularly among birds of over 4 weeks of age could be substantial during prolonged period of hot weather, also, Ubosi (1986) stated that mortality is usually high in the sub-sahelian zone of Nigeria during the hot season (March - June) and that some poultry farmers prefer closing down to staying in business during the hot period.

\subsection{Feed cost analysis}

Economic analyses of the cost of feed for various treatments are presented in Table 5. Diets fort treatments 2,3 and 4 were significantly $(\mathrm{P}<0.05)$ more expensive than that of treatment 1 (control) but there were no significant $(\mathrm{P}>0.05)$ differences between $\mathrm{T}_{2}$ and $\mathrm{T}_{3}$ treatment groups. The cost of feed in treatment 4 was significantly $(\mathrm{P}<0.05)$ higher than all the other treatments.

It should be noted that even if the birds were sold according to body weight, the difference would not have been much because no significant $(\mathrm{P}>0.05)$ difference existed in the body weight gain of the birds. However, the birds in $\mathrm{T}_{1}$ recorded the highest mortality, 4 against 2 recorded in each of the other treatment groups. It appears that the oxymed injectable contributed in the reduction of mortality rates in $T_{2}-T_{4}$ during the experimental period.

\section{Conclusion}

The results obtained from this study indicates that the supplementation of antibiotics and vita-stress have beneficial $(\mathrm{P}<0.05)$ effects in terms of growth (live weight gain), feed consumption and feed efficiency at various stages of broiler growth but did not result in any significant $(\mathrm{P}>0.05)$ difference in those parameters at maturity (nine weeks of age), instead the antibiotic and vita-stress supplements resulted in higher cost of production in comparison with the control. It was however, observed that the birds in the control group recorded the highest mortality rate which is an indication that they were more susceptible to very high ambient temperature which prevailed during the experimental period than the others. The mean day temperature was $40^{\circ} \mathrm{C}$. Therefore supplementation of broiler diet with antibiotic or vita-stress or both resulted in significant $(\mathrm{P}<0.05)$ decreases in mortality of birds in the treatment groups in a hot dry environment but resulted in higher production costs.

\section{References}

[1] Berger, L. R., Harish, C. S. and Neginius, J. (1952). Factors Affecting the Growth Response of Chicks and Turkeys Poults to Antibiotics. Poult, Sc. 31: 1070 - 1074.

[2] Brander, C. P. (1986). Effectiveness of Antibiotic. Zoo and Wild Animal: Med. J. 15(13): 392 - 394.

[3] Briggs, G. M. (1950). Antibiotics in Poultry Rations. Feedstuffs 22 No.32.12.

[4] Cantor, G. H. and Johnson, Y. H. (1983). Effect of Unidentified Growth factor Sources on Feed Preference of Chicks. Poult. Sci. 62(7): $1281-1286$

[5] Fernandez, P., Mannis, B. and Meginnis, J. (1973). Influence of Diet Composition on Chick Growth Response to Different Antibiotics, Feed Additives and Composition of the Additives. Poult. Sci. 52: 2299 - 2305.

[6] Kelly, M. and Potter, L. M. (1971). Protein Requirement and Value of Added Fat and Antibiotics in Diet of Broiler Chicken. Poult. Sci. 50: 1590 .

[7] McDougald, L. R. and Mcguisition, T. E. (1980). Mortality from Heat Stress in Broiler Chickens Influence by Anti-coccidial Drugs. Poult. Sci. 59: 2421-2423.

[8] Mange, H. (1973). Lack of Growth Response of eight Weeks old Broilers to certain Antibiotics. Poult. Sci. 53: 89 - 1895

[9] Steel, R. G. D. Torrie, J. M. (1980). Principles and Procedures of Statistics. McGraw Hill Book. Comp. N. Y.

[10] Ubosi, C. O. (1986). Poultry Production in the Livestock Industry in Nigeria. Paper Presented at Association of Veterinary Medical Students (AVMS) Symposium on august 28th, 1986 at the University of Maiduguri. 
The influence of oxytetracycline and vita-stress supplement on the productive performance of broile

Table 1: The average weekly live weight gain $(\mathrm{g})$ of broiler chickens fed diets supplemented with oxytetracycline antibiotic and vita-stress vitamin supplement.

Treatments

\begin{tabular}{|c|c|c|c|c|}
\hline $\begin{array}{c}\text { Age } \\
\text { (Week) }\end{array}$ & $\begin{array}{c}\text { T1 } \\
\text { Basal Diet Only } \\
(\text { Control })\end{array}$ & $\begin{array}{c}\text { T2 } \\
\text { Basal Diet }+ \\
\text { Oxymed Injectable }\end{array}$ & $\begin{array}{c}\text { T3 } \\
\text { Basal Diet + Vita- } \\
\text { Stress via Water }\end{array}$ & $\begin{array}{c}\text { T4 } \\
\text { Basal Diet }+ \\
\text { Oxymed Injectable } \\
+ \text { Vita-Stress via } \\
\text { Water }\end{array}$ \\
\hline 1. & $99.21 \pm 5.57^{d}$ & $101.51 \pm 5.56^{\mathrm{c}}$ & $105.71 \pm 3.81^{b}$ & $110.00 \pm 5.29^{a}$ \\
\hline 2. & $142.86 \pm 2.45^{\mathrm{d}}$ & $148.57 \pm 2.39^{c}$ & $183.57 \pm 1.52^{\mathrm{b}}$ & $193.57 \pm 1.86^{\mathrm{a}}$ \\
\hline 3. & $160.43 \pm 1.28^{c}$ & $175.09 \pm 3.21^{b}$ & $182.86 \pm 3.68 \mathrm{a}^{\mathrm{b}}$ & $185.00 \pm 2.65^{\mathrm{a}}$ \\
\hline 4. & $308.57 \pm 1.46^{\mathrm{a}}$ & $295.00 \pm 2.94^{b}$ & $260.70 \pm 3.06^{\mathrm{d}}$ & $281.43 \pm 1.90^{c}$ \\
\hline 5. & $368.57 \pm 2.19^{b}$ & $365.71 \pm 3.13^{b}$ & $377.14 \pm 2.11^{\mathrm{a}}$ & $374.29 \pm 2.191$ \\
\hline 6. & $520.71 \pm 3.99^{c}$ & $531.42 \pm 8.92^{b}$ & $532.86 \pm 4.01^{\mathrm{b}}$ & $570.00 \pm 11.26^{\mathrm{a}}$ \\
\hline 7. & $630.43 \pm 12.63^{\mathrm{d}}$ & $642.86 \pm 3.96^{\mathrm{b}}$ & $648.57 \pm 5.30^{\mathrm{a}}$ & $635.71 \pm 4.15^{\mathrm{c}}$ \\
\hline 8. & $430.86 \pm 11.55^{\mathrm{d}}$ & $496.43 \pm 14.54^{\mathrm{a}}$ & $450.00 \pm 10.43^{b}$ & $445.77 \pm 3.08^{c}$ \\
\hline 9. & $530.86 \pm 6.21^{\mathrm{b}}$ & $500.71 \pm 2.83^{c}$ & $498.86 \pm 4.41$ & $581.43 \pm 8.79^{a}$ \\
\hline Overall Mean + SEM & $354.50 \pm 13.11$ & $361.87 \pm 18.77$ & $359.36 \pm 16.58$ & $362.69 \pm 17.82$ \\
\hline
\end{tabular}

$\mathrm{a}, \mathrm{b}, \mathrm{c} \ldots$ means \pm SEM within the same row bearing different superscripts differ significantly $(\mathrm{P}<0.05)$

SEM: Standard error mean

Table 2: The average weekly feed consumption (g) of broiler chickens fed diets supplemented with oxytetracycline antibiotic and vita-stress vitamin supplement.

Treatments

\begin{tabular}{ccccc}
\hline $\begin{array}{c}\text { Age } \\
\text { (Week) }\end{array}$ & $\begin{array}{c}\text { T1 } \\
\text { Basal Diet Only } \\
\text { (Control) }\end{array}$ & $\begin{array}{c}\text { T2 } \\
\text { Basal Diet + } \\
\text { Oxymed Injectable }\end{array}$ & $\begin{array}{c}\text { T3 } \\
\text { Basal Diet + Vita- } \\
\text { Stress via Water }\end{array}$ & $\begin{array}{c}\text { T4 } \\
\text { Basal Diet + } \\
\text { Oxymed Injectable } \\
+ \text { Vita-Stress via } \\
\text { Water }\end{array}$ \\
\hline 1. & $213.77 \pm 7.55^{\mathrm{a}}$ & $200.00 \pm 6.56^{\mathrm{d}}$ & $207.14 \pm 2.16^{\mathrm{c}}$ & $211.43 \pm 1.27^{\mathrm{b}}$ \\
2. & $371.43 \pm 1.22^{\mathrm{a}}$ & $357.14 \pm 6.13^{\mathrm{b}}$ & $342.86 \pm 1.77^{\mathrm{c}}$ & $357.16 \pm 5.94^{\mathrm{b}}$ \\
3. & $350.00 \pm 6.86^{\mathrm{c}}$ & $364.30 \pm 6.37^{\mathrm{b}}$ & $364.29 \pm 8.94^{\mathrm{b}}$ & $371.43 \pm 7.94^{\mathrm{a}}$ \\
4. & $592.86 \pm 4.36^{\mathrm{a}}$ & $571.54 \pm 12.02^{\mathrm{b}}$ & $514.29 \pm 5.98^{\mathrm{d}}$ & $542.86 \pm 4.02^{\mathrm{c}}$ \\
5. & $778.57 \pm 7.39^{\mathrm{b}}$ & $782.86 \pm 8.26^{\mathrm{a}}$ & $771.43 \pm 6.76^{\mathrm{c}}$ & $770.00 \pm 7.01^{\mathrm{c}}$ \\
6. & $1021.43 \pm 13.26^{\mathrm{b}}$ & $1071.43 \pm 6.00^{\mathrm{a}}$ & $1007.14 \pm 5.13^{\mathrm{c}}$ & $981.43 \pm 7.06^{\mathrm{d}}$ \\
7. & $1035.71 \pm 6.15^{\mathrm{b}}$ & $1028.57 \pm 3.98^{\mathrm{c}}$ & $1051.43 \pm 6.98^{\mathrm{a}}$ & $1050.00 \pm 5.64^{\mathrm{a}}$ \\
8. & $1278.57 \pm 8.40^{\mathrm{b}}$ & $1288.57 \pm 12.26^{\mathrm{a}}$ & $1271.43 \pm 2.46^{\mathrm{c}}$ & $1278.60 \pm 6.68^{\mathrm{b}}$ \\
9. & $1300.37 \pm 4.78^{\mathrm{d}}$ & $1357.71 \pm 7.49^{\mathrm{a}}$ & $1342.86 \pm 2.37^{\mathrm{c}}$ & $1344.29 \pm 7.64^{\mathrm{b}}$ \\
\hline
\end{tabular}

$\mathrm{a}, \mathrm{b}, \mathrm{c} . .$. means \pm SEM within the same row bearing different superscripts differ significantly $(\mathrm{P}<0.05)$

SEM: Standard error mean

Table 3: The average weekly feed efficiently ( $\mathrm{g}$ feed) of broiler chickens fed diets $\mathrm{g}$ gain supplemented with oxytetracycline antibiotic and vita-stress vitamin supplement.

Treatments

\begin{tabular}{ccccc}
\hline $\begin{array}{c}\text { Age } \\
\text { (Week) }\end{array}$ & T1 & T2 & T3 & T4 \\
\hline 1. & 2.20 & 2.00 & 2.00 & 1.909 \\
2. & 2.60 & 2.40 & 1.90 & 1.90 \\
3. & 2.70 & 2.10 & 2.00 & 2.00 \\
4. & 1.90 & 1.90 & 2.00 & 1.90 \\
5. & 2.10 & 2.10 & 2.00 & 2.10 \\
6. & 2.10 & 2.00 & 1.90 & 1.70 \\
7. & 1.70 & 1.60 & 1.60 & 1.70 \\
8. & 3.30 & 2.70 & 2.80 & 2.90 \\
9. & 1.90 & 2.80 & 2.70 & 3.50 \\
Overall Mean + SEM & $\mathbf{2 . 2 8} \pm \mathbf{0 . 5 0}$ & $\mathbf{2 . 1 8} \pm \mathbf{0 . 3 9}$ & $\mathbf{1 . 1 0} \pm \mathbf{0 . 3 9}$ & $\mathbf{2 . 1 7} \pm \mathbf{0 . 6 2}$ \\
\hline
\end{tabular}


The influence of oxytetracycline and vita-stress supplement on the productive performance of broile

Table 4: Mortality recorded among broiler chickens fed diets supplemented with oxytetracycline antibiotic and vita-stress vitamin supplement.

Treatments

\begin{tabular}{ccccc}
\hline Age & & & T3 & T4 \\
(Week) & T1 & T2 & 0 & 0 \\
$1-7$ & 0 & 2 & 2 & 2 \\
\% Mortality & 4 & $\mathbf{1 6 . 6 7}$ & $\mathbf{1 6 . 6 7}$ & $\mathbf{1 6 . 6 7}$ \\
\hline
\end{tabular}

Table 5: Economic analysis of feeding broiler chickens with diets supplemented with oxytetracycline antibiotic and vita-stress vitamin supplement.

Treatments

\begin{tabular}{lcccc}
\hline \multicolumn{1}{c}{ Parameter } & T1 & T2 & T3 & T4 \\
\hline Cost of day-old chick/bird ( & 65.00 & 65.00 & 65.00 & 65.00 \\
Total feed consumed per bird (kg) & 3.89 & 4.25 & 3.41 & 4.17 \\
Cost of feed/bird (\#) & 101.70 & 111.13 & 88.80 & 108.81 \\
Cost of antibiotic/bird (\#) & - & 10.40 & - & 10.40 \\
Cost of vitamin supplement/bird ( & - & - & 49.20 & 49.20 \\
Mortality & 4 & 2 & 2 & 2 \\
Total cost incurred (\#) & 170.59 & 190.78 & 206.41 & 237.58 \\
Revenue from sale of bird (unit price (\#)) & 300.00 & 300.00 & 300.00 & 300.00 \\
Net profit/bird ( $)$ & 129.41 & 109.22 & 93.59 & 62.42 \\
\hline
\end{tabular}

